Part of Journal of Research of the National Bureau of Standards, Volume 20, May 1938

\title{
ANALYSIS OF PHOSPHATE ROCK
}

\author{
By James I. Hoffman and G. E. F. Lundell
}

\section{ABSTRACT}

The methods used at the National Bureau of Standards in the analysis of the two Standard Samples of Phosphate Rock, 56a and 120, are described, and a summary of the results obtained by nine cooperating analysts is given. The usual chemical analysis is supplemented by a qualitative spectrochemical examination, and one constituent, boric oxide, has been quantitatively determined by chemical and spectrochemical methods.

\section{CONTENTS}

I. Introduction 608

II. General discussion

1. Moisture _.

2. Phosphoric anhydride $\ldots \ldots$

3. Ferric oxide and alumina _...

4. Calcium oxide

5. Magnesia _...

6. Fluorine $\ldots \ldots \ldots \ldots 10$

7. Silica

8. Manganese oxide. 611

III. Methods of analysis

1. Determination of moisture _.

2. Phosphoric anhydride.......... 612

(a) Preparation of the solution _............. 612

(b) Determination of phosphoric anhydride .......... 612

3. Total ferric oxide

(a) Preparation of the solution _.............. 613

(b) Determination of total ferric oxide

4. Total alumina

(a) Preparation of the solution

(b) Determination of total alumina in the presence of less than 0.5 percent of magnesia

(c) Determination of total alumina in materials containing more than 0.5 percent of magnesia . . . . . . 616

5. Soluble ferric oxide and alumina

(a) Preparation of the solution

(b) Determination of soluble ferric oxide and alumina $\ldots 616$

6. Total calcium oxide.

(a) Preparation of the solution

(b) Determination of total calcium oxide

7. Determination of magnesia _ _ _ _ _

8. Determination of fluorine

9. Determination of silica

10. Determination of manganese oxide $(\mathrm{MnO})$

11. Determination of the alkalies

12. Determination of sulfur

13. Spectrochemical analysis (boron)

(a) Qualitative examination 623

(b) Quantitative determination of boron

IV. Summary of the results obtained in the cooperative analysis of phosphate rocks. 


\section{INTRODUCTION}

In analyzing the Standard Samples of Phosphate Rocks, 56a and 120 , issued by the National Bureau of Standards, a number of improvements in old methods were made, and some new ones were developed. Most of the methods that were used when the first Standard Sample of Phosphate Rock was issued are still in use, but many of them have been modified to such an extent that the publication of the new and revised methods seems desirable. This paper brings the previous methods ${ }^{1}$ up-to-date, but the discussion given in the former paper is not repeated. Certain modifications and suggestions by the analysts who cooperated in this work are incorporated in the discussion, but only the methods used at this Bureau are given in section III, Methods of Analysis.

\section{GENERAL DISCUSSION}

\section{MOISTURE}

The moisture content of air-dried samples of finely ground phosphate rock may vary considerably with changes in atmospheric conditions. All of the present work was therefore done on samples dried for 1 hour at $105^{\circ} \mathrm{C}$, so that the results reported by all the analysts might have a common basis. Tests at this Bureau indicated that a variation of $\pm 5^{\circ} \mathrm{C}$ in the temperature is permissible in the case of these particular rocks, and that even if a sample is exposed for 40 hours in an atmosphere of carbon dioxide saturated with water and then dried, its weight is practically the same as it would have been if it had been dried without this severe exposure. ${ }^{2}$

\section{PHOSPHORIC ANYHDRIDE}

Most of the cooperating analysts used either the alkalimetric or the gravimetric method recommended by the Association of Official Agricultural Chemists. ${ }^{3}$ The alkalimetric method involves precipitating the phosphate as ammonium phosphomolybdate in acid solution, dissolving the precipitate in an excess of a standard solution of sodium hydroxide, and then titrating the excess with standard nitric acid. In the gravimetric method the ammonium phosphomolybdate is dissolved in dilute ammonium hydroxide, and the phosphate is then precipitated as magnesium ammonium phosphate and ignited to the pyrophosphate, $\mathrm{Mg}_{2} \mathrm{P}_{2} \mathrm{O}_{7}$. The volumetric method is used almost exclusively in control laboratories and yields fairly accurate results in a very short time if conditions are closely controlled, especially if the sodium hydroxide is standardized by means of a standard sample of phosphate rock. The gravimetric method, involving only one precipitation with magnesia mixture, yields results that are slightly high, usually about 0.2 percent.

In the standardization of Samples 56a and 120, only gravimetric methods involving two precipitations with magnesia mixture were

1 The analysis of phosphate rock, J. Assn. Official Agr. Chem. 8, 184 (1924).

2 In a private communication, W. H. MacIntire, chemist of the Tennessee Valley Authority, Knoxville, Tenn., states that more uniform results are obtained if their superphosphates and "metaphosphates" are dried at room temperature for 24 to 48 hours over sulfuric acid in a partially evacuated desiccator, than if they are dried in an oven at $105^{\circ} \mathrm{C}$.

3 Official and Tentative Methods of Analysis of the Association of Official Agricultural Chemists, p: 18-22, 4th ed. (1935), published at Washington, D. C. 
used at this Bureau, because previous work ${ }^{4}$ showed that such a procedure is necessary if accurate results are desired. Two such methods were employed. One involves a precipitation of the phosphate as ammonium phosphomolybdate, followed by two precipitations with magnesia mixture, and is described in detail elsewhere. ${ }^{5}$ The other is the recently published method ${ }^{6}$ in which two precipitations with strong magnesia mixture in the presence of ammonium citrate serve to separate the phosphate from all the other constituents of the phosphate rock without the preliminary precipitation with molybdate reagent.

For comparison, the results obtained at this Bureau by the official gravimetric method of the Association of Official Agricultural Chemists are included in the Summary (tables 2 and 3 ).

\section{FERRIC OXIDE AND ALUMINA}

Total ferric oxide and alumina are seldom determined. The manufacturers of fertilizers are usually interested only in "soluble iron and alumina." To keep the results on a common basis, the cooperating analysts have agreed that the percentages of soluble $\mathrm{Fe}_{2} \mathrm{O}_{3}$ and $\mathrm{Al}_{2} \mathrm{O}_{3}$ shall represent the amounts dissolved by transferring a $2.5-\mathrm{g}$ sample to a $250-\mathrm{ml}$ flask, adding $50 \mathrm{ml}$ of diluted hydrochloric acid $(1+1)$ containing $1 \mathrm{~g}$ of boric acid, covering the neck of the flask with a watch glass, and boiling for 30 minutes. Tests have shown that the boric acid has practically no effect on the results, but that attack on the glassware by the fluorine in the rock is somewhat lessened.

By analysis of synthetic solutions containing known amounts of alumina, the method for soluble alumina described in the succeeding pages has been found to yield accurate results. Some of the cooperating analysts obtained satisfactory results by shorter methods, usually of an empirical nature. Such methods are not objectionable, especially if the general type of the rock to be analyzed is known. The preparation of the solution is probably the most important part of this determination, because it is essential that all the analysts start with solutions containing the same amount of dissolved material.

Considerable quantities of alumina are retained by the precipitate obtained with sodium hydroxide if this reagent is used for separating iron and other elements from aluminum in materials containing appreciable quantities of magnesium. ${ }^{7}$ The error caused by this retention may become serious in the analysis of some of the newer fertilizers of high magnesia content.

In the determination of total ferric oxide and alumina a mixture of perchloric, hydrochloric, and nitric acids is recommended for decomposing the material, because this mixture effects a rapid and fairly complete decomposition of phosphate rocks, and at the same time eliminates fluorine, which might cause errors in the determination of iron. ${ }^{8} \quad$ Nitric acid should always be used with perchloric acid in this attack because, without its use, serious explosions may occur as a result of the rapid interaction of perchloric acid and the organic matter contained in most phosphate rocks.

\footnotetext{
${ }^{4}$ BS J. Research 5, 279 (1930) RP200.

o J. Assn. Official Agr. Chem. 8, 194 (1924)

${ }^{6}$ Determination of phosphoric anhydride in phosphate rock, superphosphate and "metaphosphate." J. Research NBS 19, 59 (1937) RP1010.

7 G. E. F. Lundell, J. I. Hoffman, and H. A. Bright, Chemical Analysis of Iron and Steel, p. 545 (J. Wiley \& Sons, New York, N. Y., 1931).

8 W. F. Hillebrand and G. E. F. Lundell, Applied Inorganic Analysis, p. 775-776 (J. Wiley \& Sons, New York, N. Y., 1929).
} 


\section{CALCIUM OXIDE}

Total calcium oxide was determined by precipitating the calcium as oxalate in a slightly acid ( $\mathrm{pH}, 3$ to 4 ) solution. Bromphenol blue was used as the indicator in adjusting the acidity, and two precipitations were made to free the calcium oxalate from phosphate, iron, and aluminum.

\section{MAGNESIA}

Most of the analysts determined magnesia by the method ${ }^{9}$ published at this Bureau in 1932 or by some slight modification of it. In this method calcium is removed by precipitating it as sulfate in alcoholic solution, and the magnesia is then determined in the filtrate (after evaporating the alcohol) by precipitating it with phosphate in the presence of ammonium citrate, and igniting the magnesium ammonium phosphate to magnesium pyrophosphate, $\mathrm{Mg}_{2} \mathrm{P}_{2} \mathrm{O}_{7}$.

\section{FLUORINE}

If a phosphate rock is fused with sodium carbonate and the cooled melt is leached with water, much fluorine remains in the insoluble residue. ${ }^{10}$ For example, by such a treatment of 0.5 -g samples of Phosphate Rocks 56a and 120,1.4 and 1.6 percent of fluorine out of a total of 3.5 and 3.8 percent, respectively, were retained by the insoluble residue. The work of Reynolds and Jacob shows that three fusions and extractions usually do not yield more than 90 percent of the fluorine. As it is obviously impracticable to separate it by such a procedure, analysts who determine fluorine in phosphatic materials almost always resort to a method involving distillation.

All the analysts who determined fluorine distilled it by the method of Willard and Winter ${ }^{11}$ or by some modification of it. Perchloric acid was used by cooperating analysts 7 and 9 (tables 2 and 3). Egbert Janes and H. H. Edwards maintained temperatures between 135 and $140^{\circ} \mathrm{C}$ in the distilling flask, by dropping water into the solution during the distillation. A flask fitted with a dropping funnel and thermometer similar to that shown in figure 1 was used. The analysts of the U. S. Department of Agriculture maintained temperatures between 120 and $150^{\circ} \mathrm{C}$ by passing steam into the flasks during the distillation. ${ }^{12}$ It was observed in both of the laboratories mentioned that free sulfur or pyritic sulfur in the phosphate rock causes high results for fluorine if the distillate is titrated with thorium nitrate. In the laboratory of the Department of Agriculture this difficulty is overcome by redistillation. Janes and Edwards state that this interference can be prevented by igniting the sample at a low temperature in a silica dish before transferring it to the distilling flask.

Because of the dangers attending the use of perchloric acid for decomposing materials containing organic matter, ${ }^{13}$ especially if nitric acid can not be used as a preliminary oxidizer during the heating, it was deemed advisable to develop a method in which perchloric acid is not used. At the National Bureau of Standards the fluorine was

- The determination of magnesia in phosphate rock, BS J. Research 9, 487 (1932) RP484.

10 See also, D. S. Reynolds and K. D. Jacob, Ind. Eng. Chem. Anal. Ed. 3, 366 (1931).

11 H. H. Willard and O. B. Winter, Ind. Eng. Chem. Anal. Ed. 5, 7 (1933).

12 D. S. Reynolds, J. B. Kershaw, and K. D. Jacob, J. Assn. Official Agr. Chem. 19, 156 (1936).

13 Practically all phosphate rocks contain organic carbon. See K. D. Jacob, W. L. Hill, H. L. Marshall, and D. S. Reynolds, Tech. Bul. 364, p. 51 (1933) U. S. Department of Agriculture, Washington, D. C. 
therefore distilled from a sulfuric acid ${ }^{14}$ solution and determined in the distillate by the lead chlorofluoride method. ${ }^{15}$ At the temperature used in this distillation $\left(160\right.$ to $\left.170^{\circ} \mathrm{C}\right)$, a little sulfuric acid passes into the distillate, but this does not interfere in the lead chlorofluoride method.

Willard and Winter indicated that they obtained complete recovery of fluorine from fluorite $\left(\mathrm{CaF}_{2}\right)$, phosphate rock, or cryolite by direct decomposition and distillation with perchloric acid. By the method described in the succeeding pages, using the apparatus shown in figure 1, complete recovery of fluorine from fluorite was not obtained by the use of either sulfuric or perchloric acid. By first fusing the sample with sodium carbonate and then distilling, complete recovery was obtained. The difference (0.1 to 0.2 percent) between the results obtained with fused and unfused samples of phosphate rock is probably too small to warrant the introduction of this extra step in the method. For routine work, fusion probably is never necessary, but since it is not definitely known how the fluorine is combined in all types of phosphate rock, the analyst should make determinations with and without preliminary fusions to find out whether direct treatment with acid and distillation will yield satisfactory recovery in the type of material being analyzed.

\section{SILICA}

Owing to the difficulty of separating all the fluorine from the insoluble residue that is left when the cooled melt of a sodium carbonate fusion of a phosphate rock is leached with water, the determination of silica is even more difficult in this case than in glasses, enamels, or other materials that contain little or no phosphorus. In fact, no reasonably rapid and accurate method is available. The one here described, although somewhat of a makeshift, is the best expedient available. The determination of silica therefore remains the most difficult and least satisfactory in the entire analysis.

In the method described, two fusions with sodium carbonate and leachings of the cooled melts with water serve to separate most of the fluorine from the insoluble residue, which still contains some of the silica.

The silica in the alkaline solutions is separated from the fluorine in the usual way, ${ }^{16}$ by first precipitating most of it with zinc nitrate and then the remainder with zinc oxide dissolved in ammonium hydroxide. The silica in the insoluble residue is obtained by adding boric acid to lessen the effect of the fluorine which is still retained, and then dissolving the residue in hydrochloric acid and dehydrating in the usual manner.

\section{MANGANESE OXIDE}

By far the most satisfactory method for the determination of manganese oxide in phosphate rock is that in which it is determined colorimetrically after oxidation to permanganic acid by sodium or potassium periodate in strong acid solution.

\footnotetext{
14 The use of phosphoric acid has also been suggested for this distillation.

$15 \mathrm{~J}$. I. Hoffman and G. E. F. Lundell, Determination of fluorine and of silica in glasses and enamels containing fluorine, BS J. Research 3, 581 (1929) RP110.

10 BS J. Research 3, 581 (1929) RP110.
} 


\section{METHODS OF ANALYSIS}

\section{DETERMINATION OF MOISTURE}

Place $5.00 \mathrm{~g}$ of sample in a glass-stoppered weighing bottle of such diameter that the depth of the sample does not exceed $0.5 \mathrm{~cm}$. Dry for 1 hour at $105^{\circ} \mathrm{C}$ in a well-ventilated oven. At the end of 1 hour, loosely stopper the bottle, and cool in a desiccator. Momentarily raise the stopper, again put it in place, and weigh. The loss in weight is regarded as moisture.

\section{PHOSPHORIC ANHYDRIDE}

\section{(a) PREPARATION OF THE SOLUTION}

Method A.-Transfer $2.500 \mathrm{~g}$ of the dried material to a $300-\mathrm{ml}$ Erlenmeyer flask, add $30 \mathrm{ml}$ of hydrochloric acid and $10 \mathrm{ml}$ of nitric acid. Place a small watch glass over the mouth of the flask, and boil gently for 30 minutes. Rinse the glass, add $50 \mathrm{ml}$ of water, heat to boiling, and filter through a paper of close texture, catching the filtrate in a $250-\mathrm{ml}$ volumetric flask. Wash the paper ${ }^{17}$ and the Erlenmeyer flask thoroughly with diluted hydrochloric acid ${ }^{18}(1+4)$, cool the contents of the volumetric flask to the proper temperature, and add water until the flask is filled to the mark. Mix thoroughly and transfer $50.00 \mathrm{ml}$ of the solution (representing $0.5000 \mathrm{~g}$ of sample) to a $300-\mathrm{ml}$ Erlenmeyer flask.

Method B.-Transfer $0.5000 \mathrm{~g}$ of the dried material to a $300-\mathrm{ml}$ Erlenmeyer flask and add $15 \mathrm{ml}$ of hydrochloric acid and $3 \mathrm{ml}$ of nitric acid. Place a small watch glass over the mouth of the flask, and boil gently for 30 minutes. Rinse and remove the watch glass, and without filtering, proceed with the addition of ammonium citrate, hydrochloric acid, and magnesia mixture.

This method obviates the use of volumetric glassware and requires less time than method $A$. The results obtained are equally accurate if the material contains no appreciable amount of compounds of phosphorus insoluble in this mixture of acids.

\section{(b) DETERMINATION OF PHOSPHORIC ANHYDRIDE ${ }^{10}$}

To the solution in the 300 -ml Erlenmeyer flask, add $30 \mathrm{~g}$ of ammonium citrate, $10 \mathrm{ml}$ of hydrochloric acid, and $100 \mathrm{ml}$ of strong magnesia mixture. ${ }^{20}$ Neutralize the solution with ammonium hydroxide, using litmus paper as indicator, and add $3 \mathrm{ml}$ of ammonium hydroxide in excess. Dilute the solution to 225 to $250 \mathrm{ml}$ with water, add a few glass beads, stopper the flask tightly, shake on a shaking

${ }_{17} \mathrm{By}$ applying the treatment prescribed, no phosphorus is volatilized, and only 0.03 percent of $\mathrm{P}_{2} \mathrm{O}_{5}$ remained in the insoluble residue in the case of the National Bureau of Standards Sample 56, and less than 0.005 percent in Samples 56a and 120. Unless it is known that no phosphorus remains insoluble, ignite the paper and insoluble residue in platinum, fuse with a small quantity of sodium carbonate, and leach the cooled melt with hot water. Filter, acidify the filtrate with hydrochloric acid, and add the solution to the contents of the volumetric flask. Or, if the filtrate is acidified with nitric acid, the phosphorus may be precipitated with molybdate reagent, separately determined, and the percentage found added to that obtained in the main determination.

18 This denotes 1 volume of concentrated hydrochloric acid (sp gr 1.18) diluted with 4 volumes of water. Diluted ammonium hydroxide $(1+19)$ denotes 1 volume of ammonium hydroxide (sp gr 0.90$)$ diluted with 19 volumes of water. If no dilution is specified, the concentrated reagent is meant. This system of specifying dilution is used throughout this paper.

19 This method is described in detail in J. Research NBS 19, 59 (1937) RP1010.

20 Prepare the strong magnesia mixture as follows: Dissolve $400 \mathrm{~g}$ of $\mathrm{MgCl}_{2} .6 \mathrm{H}_{2} \mathrm{O}$ and $300 \mathrm{~g}$ of ammonium chloride in $1,500 \mathrm{ml}$ of warm water. When solution is complete, add ammonium hydroxide until the solution is alkaline to litmus. Allow to stand for about 1 hour, filter, and add hydrochloric acid to the filtrate until the solution is acid to litmus. If properly prepared, the volume of the solution will be almost exactly 2 liters. 
machine for about 30 minutes and allow to stand overnight. Filter through a paper of close texture, and wash the flask and paper once with a small quantity of diluted ammonium hydroxide $(1+19)$. Discard the filtrate.

Dissolve any magnesium ammonium phosphate remaining in the flask in about $50 \mathrm{ml}$ of warm diluted hydrochloric acid $(1+4)$ and pour the solution through the paper to dissolve the phosphate that was transferred to the filter, and to separate any insoluble residue that may have remained if method $B$ was used for the preparation of the solution. Wash the paper and flask with more of the same acid, and add $0.3 \mathrm{~g}$ of citric acid and $1 \mathrm{ml}$ of magnesia mixture to the solution, which should have a volume of about $100 \mathrm{ml}$. While stirring, add ammonium hydroxide until the solution is alkaline to litmus, and then add $5 \mathrm{ml}$ in excess. Stir occasionally during 30 minutes, and allow to stand for 4 hours or overnight.

Collect the precipitate on a 9-cm paper of close texture, wash with cool diluted ammonium hydroxide $(1+19)$, and transfer the paper and precipitate to a weighed platinum or porcelain crucible. Char the paper without flaming, burn off the carbon below $900^{\circ} \mathrm{C}$, and finally ignite to constant weight, preferably in a muffle furnace with pyrometric control, at 1,050 to $1,100^{\circ} \mathrm{C}$.

The weight of the magnesium pyrophosphate, $\mathrm{Mg}_{2} \mathrm{P}_{2} \mathrm{O}_{7}$, multiplied by 63.79 and divided by the weight of the sample, yields the percentage of $\mathrm{P}_{2} \mathrm{O}_{5}$.

Tests have shown that in the analysis of phosphate rock the time of standing in the first precipitation can be reduced to 3 hours and in the second to 2 hours, if the solutions are chilled before shaking or stirring and then allowed to stand in ice water or in a refrigerator at 5 to $10^{\circ} \mathrm{C}$. With small quantities (less than $10 \mathrm{mg}$ of $\mathrm{P}_{2} \mathrm{O}_{5}$ ), the longer time of standing is essential, and even then it is best to chill and shake alternately two or three times.

An alternative umpire method involving a preliminary precipitation of the phosphate with molybdate, followed by two precipitations with magnesia mixture is described in a previous publication. ${ }^{20 a}$

\section{TOTAL FERRIC OXIDE}

\section{(a) PREPARATION OF THE SOLUTION}

Transfer $2.000 \mathrm{~g}$ of the dried sample to a 300-ml Erlenmeyer flask, and add $30 \mathrm{ml}$ of diluted nitric acid $(1+2), 5 \mathrm{ml}$ of hydrochloric acid, and $10 \mathrm{ml}$ of 60 -percent perchloric acid. Place the uncovered flask on the hot plate, evaporate until fumes of perchloric acid appear, and heat just below its boiling point until nearly all the acid has been volatilized. Do not evaporate quite to dryness. Cool somewhat, and drench the residue with $5 \mathrm{ml}$ of hydrochloric acid. Add $30 \mathrm{ml}$ of warm water, and heat until salts are in solution. Remove the insoluble residue by filtering through a paper of loose texture, wash thoroughly with hot diluted hydrochloric acid $(1+19)$ and reserve the solution. Ignite the paper and residue in platinum, treat with hydrofluoric and sulfuric acids to eliminate the silica, and fuse the nonvolatile residue with a little sodium pyrosulfate. Dissolve the cooled melt in $25 \mathrm{ml}$ of diluted hydrochloric acid $(1+19)$, and precipitate the iron in the solution by adding a slight excess of ammonium

20a The analysis of phosphate rock. J. Assn. Official Agr. Chem. 8, 194 (1924). 
hydroxide. Collect the precipitate on a small filter, and wash once or twice with water. ${ }^{21}$ Dissolve the precipitate in hot diluted hydrochloric acid $(1+19)$, and add the solution to the reserved solution.

\section{(b) DETERMINATION OF TOTAL FERRIC OXIDE}

To the combined solutions add a few drops of a saturated solution of potassium permanganate, boil to expel chlorine, and then add stannous chloride dropwise until the iron is reduced, as is indicated by the disappearance of the yellow color. Avoid any large excess. Wash the inside surface of the beaker with a jet of water, cool rapidly, and add at one stroke $10 \mathrm{ml}$ of a saturated solution of mercuric chloride. Agitate the solution for 1 minute, and then pour it into a 1-liter porcelain casserole containing $20 \mathrm{ml}$ of manganese sulfate solution ${ }^{22}$ and $450 \mathrm{ml}$ of water. Titrate with a solution of potassium permanganate, not stronger than $0.1 \mathrm{~N}$, and correct the result by subtracting the volume of permanganate required in a titration of the reagents alone. Calculate the percentage of $\mathrm{Fe}_{2} \mathrm{O}_{3}$.

In most cases it is not necessary to filter and to recover the iron in the insoluble residue. The iron can be reduced with stannous chloride as soon as the salts have been dissolved in dilute hydrochloric acid after the evaporation with perchloric acid, provided that no brown or black particles remain undissolved. Mere visual observation will easily show whether it is necessary to recover iron from the insoluble residue.

The percentages of iron oxide in the insoluble residues from eight phosphate rocks were as follows: NBS Standard Tennessee Phosphate Rock 56, 0.05; NBS Standard Tennessee Phosphate Rock 56a, 0.007; NBS Standard Florida Phosphate Rock 120, 0.007; Florida pebble rock, 0.005; Florida hard rock, 0.005; Tennessee blue rock, 0.01; Wyoming phosphate rock, 0.01 ; and Idaho phosphate rock, 0.01 . It is evident that the recovery of iron is of consequence in only one of the eight insoluble residues. The amount of iron in the insoluble residue may depend on the fineness of the sample.

\section{TOTAL ALUMINA}

\section{(a) PREPARATION OF THE SOLUTION}

Transfer $2.500 \mathrm{~g}$ of the dried sample to a platinum dish, and add $30 \mathrm{ml}$ of diluted nitric acid $(1+1)$ and $10 \mathrm{ml}$ of hydrofluoric acid. Evaporate to dryness on the steam bath, then add $30 \mathrm{ml}$ of diluted nitric acid $(1+1), 5 \mathrm{ml}$ of hydrofluoric acid, and $15 \mathrm{ml}$ of 60 -percent perchloric acid. Evaporate nearly to dryness on the hot plate, cool, wash the inside surface of the dish with a jet of water, and add $5 \mathrm{ml}$ of 60-percent perchloric acid. Again evaporate nearly to dryness, cool somewhat, and add $30 \mathrm{ml}$ of diluted hydrochloric acid $(1+2)$. Heat the solution on the steam bath, and if a residue remains, collect it on a small tight filter paper. Ignite the paper in a platinum crucible, and treat the residue with a drop of sulfuric acid and about 0.5 $\mathrm{ml}$ of hydrofluoric acid. Evaporate to dryness, ignite for 1 minute at 600 to $800^{\circ} \mathrm{C}$, and fuse the residue with about $0.5 \mathrm{~g}$ of sodium carbonate. Dissolve the cooled melt in the original acid solution of the sample.

\footnotetext{
${ }^{21}$ The precipitation with ammonium hydroxide is made to eliminate traces of platinum which would otherwise interfere in the determination of iron.

${ }_{22}$ Dissolve $200 \mathrm{~g}$ of $\mathrm{MnSO}_{4} .4 \mathrm{H}_{2} \mathrm{O}$ in $1,000 \mathrm{ml}$ of $\mathrm{H}_{2} \mathrm{O}$, and add a cooled mixture of $400 \mathrm{ml}$ of $\mathrm{H}_{2} \mathrm{SO}_{4}, 1,200 \mathrm{ml}$ of $\mathrm{H}_{2} \mathrm{O}$, and $400 \mathrm{ml}$ of approximately 85 -percent phosphoric acid.
} 

PERCENT OF MAGNESIA

Nearly neutralize the warm solution $\left(60^{\circ} \mathrm{C}\right)$ having a volume of about $200 \mathrm{ml}$, with a 25 -percent solution of sodium hydroxide, and pour this solution slowly while stirring into $100 \mathrm{ml}$ of a 25 -percent solution of sodium hydroxide containing $0.5 \mathrm{~g}$ of sodium carbonate. Transfer the solution and precipitate to a $500-\mathrm{ml}$ volumetric flask, allow to cool, fill the flask to the mark with cool water, and mix thoroughly. Filter through a dry filter into a dry 200-ml volumetric flask. Two 200-ml portions may be collected if duplicate determinations are to be made.

Determine the alumina in a $200-\mathrm{ml}$ portion of the filtrate, representing $1.000 \mathrm{~g}$ of sample, by the phosphate method as follows: Acidify the solution with hydrochloric acid, add $10 \mathrm{ml}$ of the concentrated acid in excess, and then $1.0 \mathrm{~g}$ of diammonium phosphate. Dilute to 350 to $400 \mathrm{ml}$, add methyl orange indicator, make just alkaline with ammonium hydroxide, and restore the pink color with several drops of diluted hydrochloric acid $(1+5)$. Heat the solution to boiling, and add $15 \mathrm{ml}$ of a 50-percent solution of ammonium acetate. Continue the boiling for 5 minutes, and then collect the precipitate on an 11-cm filter of close texture (No. 42 Whatman or No. $589 \mathrm{~S} \&$ S blue ribbon), and allow the precipitate to drain. Without washing, transfer the paper and precipitate to the beaker in which the precipitation took place, and stir the paper to a pulp. Add $10 \mathrm{ml}$ of hydrochloric acid and $1.0 \mathrm{~g}$ of diammonium phosphate, and dilute the solution to $300 \mathrm{ml}$. Add methyl orange indicator, and precipitate the aluminum as before. Filter, and wash with a hot 5-percent solution of ammonium nitrate until $5 \mathrm{ml}$ of the washings gives at most a barely distinguishable opalescence with an acidified solution of silver nitrate. Usually, $150 \mathrm{ml}$ of wash solution is sufficient.

Ignite the paper and precipitate in platinum or porcelain. Heat at a low temperature until the carbon is gone, then at about $1,000^{\circ} \mathrm{C}$ until constant weight is obtained. Weigh as $\mathrm{AlPO}_{4}$ and multiply by 0.418 to convert to the weight of $\mathrm{Al}_{2} \mathrm{O}_{3}$. A blank should be carried through all steps of the method and the weight of the $\mathrm{AlPO}_{4}$ corrected accordingly.

In routine analyses two steps of the method may be omitted. (1) In decomposing most phosphate rocks the residue that remains undissolved after the treatments with nitric, hydrofluoric, and perchloric acids contains only a negligible amount of alumina and no calcium oxide. It therefore is usually permissible to ignore the insoluble residue, and, without filtering, to proceed with the sodium hydroxide precipitation. (2) Results are only slightly higher if only a single phosphate precipitation is made. For routine work it is therefore permissible to omit the second precipitation with phosphate. Macerated paper must, however, be added, and the washing with a solution of ammonium nitrate must be thorough.

The percentages of alumina in the insoluble residues were determined in eight phosphate rocks as follows: NBS Standard Tennessee Phosphate Rock 56, 0.03; NBS Standard Tennessee Phosphate Rock 56a, 0.02; NBS Standard Florida Phosphate Rock 120, 0.02; Florida pebble rock, 0.01; Florida hard rock, 0.005; Tennessee blue rock, 0.005 ; Wyoming phosphate rock, 0.005 ; and Idaho phosphate rock, 0.005 . 
(c) DETERMINATION OF TOTAL ALUMINA IN MATERIALS CONTAINING MORE THAN 0.5 PERCENT OF MAGNESIA

To avoid low results for alumina when 0.5 percent or more of magnesia is present, separate most of the magnesium from the aluminum as follows: To the perchloric acid solution of the sample add $50 \mathrm{ml}$ of hydrochloric acid, and dilute to $400 \mathrm{ml}$. Add methyl orange indicator solution and then ammonium hydroxide until the indicator just turns yellow. Restore the pink color by adding hydrochloric acid dropwise, heat the solution nearly to boiling, and add $15 \mathrm{ml}$ of a 50 -percent solution of ammonium acetate. Boil for 5 minutes, filter, and wash the precipitate a few times with a 5-percent solution of ammonium nitrate. Dissolve the precipitate in $30 \mathrm{ml}$ of hot diluted hydrochloric acid $(1+2)$, and proceed with the neutralization and precipitation with sodium hydroxide.

The magnitude of the error caused by magnesium is illustrated by the following determinations of magnesia in a synthetic standard prepared by mixing $2.500 \mathrm{~g}$ of National Bureau of Standards Argillaceous Limestone ${ }^{23} 1 \mathrm{~A}$ with $1.5 \mathrm{~g}$ of $\mathrm{P}_{2} \mathrm{O}_{5}$. Three determinations by the method in which magnesia is not removed, (4 (b), p. 615) indicated $3.84,3.90$, and 3.91 percent of alumina, respectively, in the limestone, whereas 4.14 and 4.17 percent, respectively, were obtained by the method in which magnesia is removed before the alumina is separated by means of sodium hydroxide (4 (c).

\section{SOLUBLE FERRIC OXIDE AND ALUMINA}

(a) PREPARATION OF THE SOLUTION

Transfer $2.500 \mathrm{~g}$ of sample to a $250-\mathrm{ml}$ flask, add $50 \mathrm{ml}$ of diluted hydrochloric acid $(1+1)$ containing $1 \mathrm{~g}$ of boric acid, cover the neck of the flask with a watch glass, and boil moderately for 30 minutes. Remove the flask from the source of heat, add $20 \mathrm{ml}$ of water, and remove the insoluble matter by filtration. Catch the filtrate in a $250-\mathrm{ml}$ volumetric flask, cool the solution, and dilute to the mark. Mix well, and remove suitable aliquot portions for the determinations of soluble ferric oxide and alumina.

(b) DETERMINATION OF SOLUBLE FERRIC OXIDE AND ALUMINA

Determine soluble ferric oxide in an aliquot portion of the prepared solution by the procedure described for total ferric oxide under 3 (b), p. 614 .

Determine soluble alumina in an aliquot portion of the prepared solution by the procedure described for total alumina under 4 (b) p. 615 or 4 (c), p. 616 .

\section{TOTAL CALCIUM OXIDE}

(a) PREPARATION OF THE SOLUTION

Prepare the solution as directed for total alumina under 4 (a) p. 614 .

(b) DETERMINATION OF TOTAL CALCIUM OXIDE

Transfer an aliquot portion of the prepared solution, representing $0.5000 \mathrm{~g}$ of sample, to a $400-\mathrm{ml}$ beaker, add $50 \mathrm{ml}$ of a saturated solution of ammonium oxalate (about $4 \mathrm{~g}$ of $\left(\mathrm{NH}_{4}\right)_{2} \mathrm{C}_{2} \mathrm{O}_{4} \cdot \mathrm{H}_{2} \mathrm{O}$ in $100 \mathrm{ml}$ of

${ }_{23}$ This limestone contains 14.11 percent of $\mathrm{SiO}_{2}, 1.63$ percent of $\mathrm{Fe}_{2} \mathrm{O}_{3}, 4.16$ percent of $\mathrm{Al}_{2} \mathrm{O}_{3}, 0.16$ percent of $\mathrm{TiO}_{2}, 41.32$ percent of $\mathrm{CaO}$, and 2.19 percent of $\mathrm{MgO}$. 
water) and dilute the solution to $200 \mathrm{ml}$. Add 2 drops of brom phenol blue indicator solution, ${ }^{24}$ and heat to 80 to $90^{\circ} \mathrm{C}$, and then add ammonium hydroxide until the color in the hot solution changes from yellow to a light green but not to a distinct blue. This yields a solution having a pH value between 3 and 4 . Digest on the steam bath for 1 to 2 hours, cool, filter through a paper of close texture, and wash the precipitate in the beaker and on the paper two or three times with ammonium oxalate-oxalic acid wash solution ( 2 of $\left(\mathrm{NH}_{4}\right)_{2} \mathrm{C}_{2} \mathrm{O}_{4} \cdot \mathrm{H}_{2} \mathrm{O}$ and $1 \mathrm{~g}$ of $\mathrm{H}_{2} \mathrm{C}_{2} \mathrm{O}_{4} \cdot 2 \mathrm{H}_{2} \mathrm{O}$ dissolved in 1 liter of water). Actual determinations of the $\mathrm{pH}$ of the solutions by means of a Cole. man Model 3D pH Electrometer showed that satisfactory results can be obtained at $\mathrm{pH}$ values between 3 and 4.4 , but that low results are obtained if the acidity is increased to a $\mathrm{pH}$ of 2.0 to 2.4 .

Transfer the paper and the precipitate to the beaker in which the calcium was precipitated, stir the paper to a pulp, and add $20 \mathrm{ml}$ of diluted hydrochloric acid $(1+1)$. Heat on the steam bath until the calcium oxalate is dissolved, add $25 \mathrm{ml}$ of a saturated solution of ammonium oxalate, dilute to $200 \mathrm{ml}$, and repeat the precipitation as previously described. Collect the precipitate on a paper of close texture, and wash with ammonium oxalate-oxalic acid wash solution. Transfer the paper and precipitate to a platinum crucible with cover, and heat in the uncovered crucible until carbon has been destroyed. Cover the crucible, ignite at $1,200^{\circ} \mathrm{C}$, and weigh as $\mathrm{CaO}+\mathrm{Mn}_{3} \mathrm{O}_{4}$. The crucible should be reheated and the weight checked because of possible absorption of moisture during the first weighing.

Part of the manganese in the original sample will be found in the ignited calcium oxide. To correct for this, dissolve the ignited residue in $50 \mathrm{ml}$ of diluted nitric acid $(1+4)$, add $5 \mathrm{ml}$ of 85 -percent phosphoric acid to the solution, and determine the manganese colorimetrically by the periodate method described under determination of manganese oxide (p. 622). Calculate the manganese to $\mathrm{Mn}_{3} \mathrm{O}_{4}$, and subtract from the weight of the ignited residue. The amount of $\mathrm{Mn}_{3} \mathrm{O}_{4}$ that accompanied the calcium oxide in the case of Sample $56 \mathrm{a}(\mathrm{MnO}=0.18$ percent) was only $0.1 \mathrm{mg}$, and with Sample $120(\mathrm{MnO}=0.027)$ it was only $0.03 \mathrm{mg}$. Therefore, no serious error is introduced if the correction for manganese is neglected in the analysis of materials containing: less than 0.2 percent of manganese oxide. The averages of four closely checking results obtained by this method for total CaO in Samples 56 , $56 \mathrm{a}$, and 120 were $44.9,45.62$, and 49.67 percent, respectively, as compared with the certificate values, $44.8,45.55$, and 49.62 percent, respectively.

The proper conditions for the precipitation of calcium in dilute acid solutions can also be obtained by the method previously described by the authors. ${ }^{24 a}$

\section{DETERMINATION OF MAGNESIA}

Transfer $2.00 \mathrm{~g}$ of the sample to a $250-\mathrm{ml}$ beaker, cover, add $15 \mathrm{ml}$ of diluted hydrochloric acid $(2+1)$ and $5 \mathrm{ml}$ of nitric acid, and boil gently for 10 to 15 minutes. Remove the beaker from the source of heat, add $6 \mathrm{ml}$ of diluted sulfuric acid $(1+1)$, remove the cover, and evaporate until fumes of sulfuric acid appear. Cool slightly,

${ }^{24}$ Prepared by dissolving $0.10 \mathrm{~g}$ of brom phenol blue reagent in $1.5 \mathrm{ml}$ of $0.1 \mathrm{~N}$ sodium hydroxide and diluting to $25 \mathrm{ml}$.

24a The Analysis of Phosphate Rock, J. Assn. Official Agr. Chem. 8, 203 (1924).

$57763-38-4$ 
wash down the inside surface of the beaker with a jet of water, and again evaporate until fumes of sulfuric acid appear. Cool, add 10 $\mathrm{ml}$ of water, stir thoroughly, and digest on the steam bath for 10 to 15 minutes. Remove from the steam bath, add $100 \mathrm{ml}$ of 95-percent alcohol, stir so that the calcium sulfate is well dispersed throughout the liquid, and then allow to stand for 30 minutes or longer. Filter by means of suction through a tight plug of filter-paper pulp, using a Gooch crucible, carbon funnel, or Büchner funnel, and wash five times with 5-ml portions of 95-percent alcohol containing $1 \mathrm{ml}$ of sulfuric acid per $100 \mathrm{ml}$.

Evaporate the alcoholic filtrate as far as possible on the steam bath. Transfer the solution to a 300-ml Erlenmeyer flask, dilute to 75 to $100 \mathrm{ml}$, and add $2 \mathrm{~g}$ of citric acid and $15 \mathrm{ml}$ of a 25-percent solution of diammonium phosphate, $\left(\mathrm{NH}_{4}\right)_{2} \mathrm{HPO}_{4}$. Add ammonium hydroxide until the solution is alkaline to litmus, and then add $10 \mathrm{ml}$ in excess. Add 5 to 10 glass beads, tightly stopper the flask, and shake on a shaking machine for at least 1 hour. Allow to stand in a cool place for 4 hours or preferably overnight. Filter through a tight paper containing a little paper pulp, and wash thoroughly with diluted ammonium hydroxide $(1+19)$, containing $50 \mathrm{~g}$ of diammonium phosphate per liter. Pass $25 \mathrm{ml}$ of hot diluted hydrochloric acid $(1+19)$ through the paper into the flask in which the precipitation took place, transfer the solution to a $150-\mathrm{ml}$ beaker, and wash the paper and flask thoroughly with more of the diluted acid. To the solution in a volume of 50 to $75 \mathrm{ml}$ and containing no glass beads, add $0.5 \mathrm{ml}$ of a 25-percent solution of diammonium phosphate, cool, and then add ammonium hydroxide, while stirring, until the solution is alkaline to litmus. Stir for a few minutes, then add 3 to $4 \mathrm{ml}$ of ammonium hydroxide and allow to stand for 4 hours or overnight. Transfer the precipitate to a small filter, and wash with diluted ammonium hydroxide $(1+19)$. Transfer the paper and precipitate to a platinum crucible, ignite slowly at a temperature below $900^{\circ} \mathrm{C}$ until the carbon is burned, preferably in a muffle furnace with pyrometric control, and then at about $1,100^{\circ} \mathrm{C}$ for 1 to 2 hours. Cool and weigh.

The residue consists of $\mathrm{Mg}_{2} \mathrm{P}_{2} \mathrm{O}_{7}$ and possibly $\mathrm{Mn}_{2} \mathrm{P}_{2} \mathrm{O}_{7}$ and $\mathrm{Ca}_{3}-$ $\left(\mathrm{PO}_{4}\right)_{2}$. If the alcoholic filtrate was clear, the tricalcium phosphate will not exceed $0.3 \mathrm{mg}$ and can be neglected unless very accurate results are desired. ${ }^{25}$ The correction for manganese is made as follows: Dissolve the residue in $10 \mathrm{ml}$ of diluted sulfuric acid $(1+9)$, transfer the solution to a $300-\mathrm{ml}$ Erlenmeyer flask, and add $50 \mathrm{ml}$ of diluted nitric acid $(1+3), 2 \mathrm{ml}$ of 85-percent phosphoric acid, and $0.5 \mathrm{~g}$ of potassium periodate, $\mathrm{KIO}_{4}$. Boil for 15 to 20 minutes, cool, and dilute to a convenient volume. In another flask containing the same amounts of the reagents treated in a similar way, match the color by adding a standard solution of potassium permanganate. From the volume of the solution of permanganate required, calculate the weight of $\mathrm{Mn}_{2} \mathrm{P}_{2} \mathrm{O}_{7}$ in the residue. Subtract this weight from the total weight, and regard the difference as $\mathrm{Mg}_{2} \mathrm{P}_{2} \mathrm{O}_{7}$, which contains 36.2 percent of $\mathrm{MgO}$.

\footnotetext{
${ }_{25}$ If a correction for calcium is to be made, dissolve the residue in $10 \mathrm{ml}$ of diluted sulfuric acid $(1+19)$, evaporate to about $5 \mathrm{ml}$, and then add $25 \mathrm{ml}$ of 95-percent alcohol. Allow to stand for 1 to 2 hours, filter on a small paper, and wash with alcohol. Dry the paper in the funnel, and dissolve the precipitate of calcium sulfate in $20 \mathrm{ml}$ of hot diluted hydrochloric acid $(1+99)$. Add a few crystals of ammonium oxalate, heat, render the solution faintly ammoniacal, and allow to stand for about 1 hour. Filter, ignite, and weigh as $\mathrm{CaO}$. Calculate to tricaleium phosphate, $\mathrm{Ca}_{3}\left(\mathrm{PO}_{4}\right)_{2}$, and subtract from the apparent weight of $\mathrm{Mg}_{2} \mathrm{P}_{2} \mathrm{O}_{7}$. If calcium is determined in this way, the alcoholic filtrate is used for the determination of manganese. Before applying the periodate oxidation, this filtrate must be evaporated and heated until fumes of sulfuric acid appear, and then treated with nitric acid to make sure that reducing substances are absent.
} 


\section{DETERMINATION OF FLUORINE}

Fuse 0.50 to $1.00 \mathrm{~g}$ of sample with $4.0 \mathrm{~g}$ of sodium carbonate in a platinum crucible. Keep the molten mass at a red heat for 5 minutes, then grasp the hot crucible with tongs, and immediately immerse the lower half in cold water. Tap the cold crucible to loosen the solidified mass, and transfer the cooled melt to a 125-ml Claissen flask (see fig. 1). Scrub the crucible and cover with a policeman and a little hot water, and transfer the washings to the flask, which rests in a 4-cm hole in an asbestos gauze $E$, and is fitted with rubber stoppers, a delivery bulb $A$ for admitting acid and water, a thermometer $D$, and a condenser $B$, which delivers the distillate into a $400-\mathrm{ml}$ beaker $C$. The end of the condenser is immersed in $20 \mathrm{ml}$ of a 20 -percent solution of sodium hydroxide contained in the beaker $C$.

Add 0.05 to $0.1 \mathrm{~g}$ of 20 to 40 -mesh flake graphite or granulated coke to prevent bumping, ${ }^{26}$ close the flask with the stopper containing the thermometer and the delivery tube $A$, admit $30 \mathrm{ml}$ of diluted sulfuric acid $(1+1)$, and cautiously heat the contents of the flask until frothing ceases. A good Tirrill or similar burner is a satisfactory source of heat. Increase the heat until the liquid in the flask boils vigorously, and continue the boiling until the temperature of the liquid has risen to

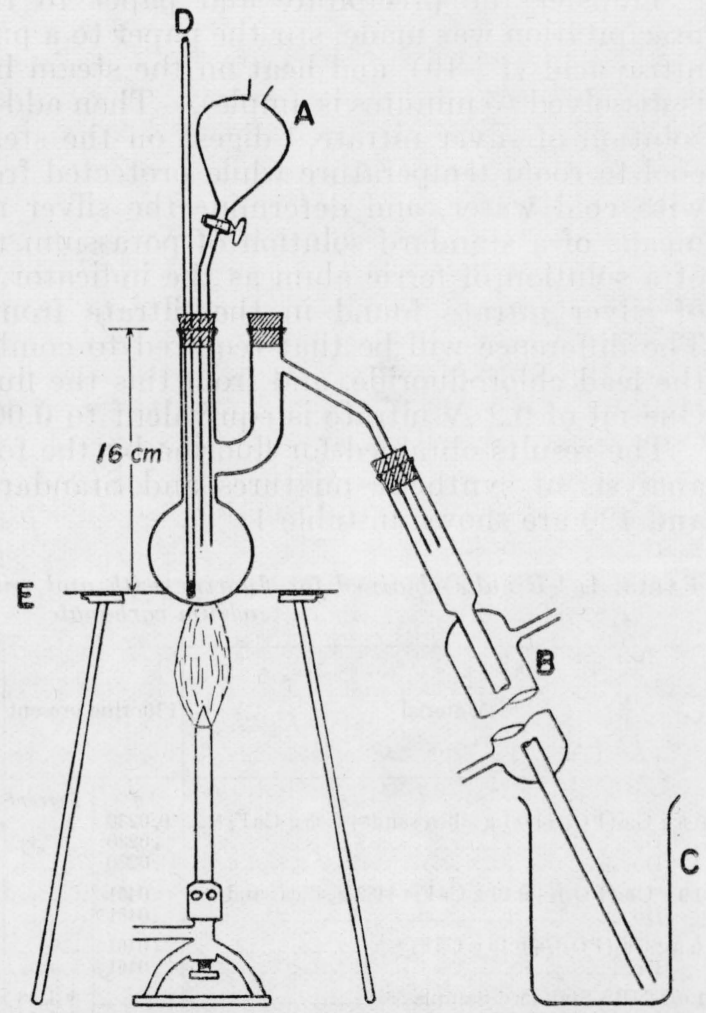

Figdre 1.-Apparatus for distilling fluorine. $160^{\circ} \mathrm{C}$. Then without removing the source of heat, admit water through the tube $A$ at such a rate that the temperature of the liquid in the flask remains between 160 and $170^{\circ} \mathrm{C}$. Collect $300 \mathrm{ml}$ of distillate between these temperatures.

Evaporate the alkaline distillate to a volume of $250 \mathrm{ml}$, and add $3 \mathrm{ml}$ of a 10-percent solution of sodium chloride and 2 drops of bromphenol blue indicator. ${ }^{27}$ Add dilute nitric acid until the color changes to yellow, and then sodium hydroxide until the color changes just to blue.

\footnotetext{
${ }^{26}$ This means of preventing bumping was suggested by W. E. Dickinson, Chief Chemist of the Inter national Agricultural Corporation, Norfolk, Va.

${ }_{27}$ Prepared by dissolving $0.10 \mathrm{~g}$ of bromphenol blue reagent in $1.5 \mathrm{ml}$ of $0.1 \mathrm{~N}$ sodium hydroxide and diluting to $25 \mathrm{ml}$.
} 
Now add $2 \mathrm{ml}$ of diluted hydrochloric acid $(1+1)$ and $5.0 \mathrm{~g}$ of solid lead nitrate, $\mathrm{Pb}\left(\mathrm{NO}_{3}\right)_{2}$, and heat on the steam bath. $\mathrm{As}$ soon as the lead nitrate is in solution, add $5.0 \mathrm{~g}$ of solid sodium acetate, $\mathrm{NaC}_{2} \mathrm{H}_{3} \mathrm{O}_{2} \cdot 3 \mathrm{H}_{2} \mathrm{O}$, stir vigorously, and digest on the steam bath for 30 minutes with occasional stirring. Allow to stand overnight at room temperature, and decant the solution through a paper of close texture (589 $S \& S$ blue ribbon or 42 Whatman). Wash the precipitate, beaker, and paper once with cold water, then four to five times with a cool saturated solution of lead chlorofluoride, ${ }^{28}$ and then once more with cold water.

Transfer the precipitate and paper to the beaker in which the precipitation was made, stir the paper to a pulp, add $100 \mathrm{ml}$ of diluted nitric acid $(1+19)$, and heat on the steam bath until the precipitate is dissolved ( 5 minutes is ample). Then add a slight excess of a $0.2 \mathrm{~N}$ solution of silver nitrate ${ }^{29}$ digest on the steam bath for 30 minutes, cool to room temperature while protected from the light, filter, wash with cold water, and determine the silver nitrate in the filtrate by means of a standard solution of potassium thiocyanate, ${ }^{30}$ using $5 \mathrm{ml}$ of a solution of ferric alum as the indicator. ${ }^{31}$ Subtract the amount of silver nitrate found in the filtrate from that originally added. The difference will be that required to combine with the chlorine in the lead chlorofluoride, and from this the fluorine may be computed. One $\mathrm{ml}$ of $0.2 \mathrm{~N}$ nitrate is equivalent to $0.00380 \mathrm{~g}$ of fluorine.

The results obtained for fluorine by the foregoing procedure in the analysis of synthetic mixtures and Standard Phosphate Rocks 56a and 120 are shown in table 1.

TABLE 1.-Results obtained for fluorine with and without preliminary fusion with sodium carbonate

\begin{tabular}{|c|c|c|c|c|c|c|}
\hline \multirow[b]{2}{*}{ 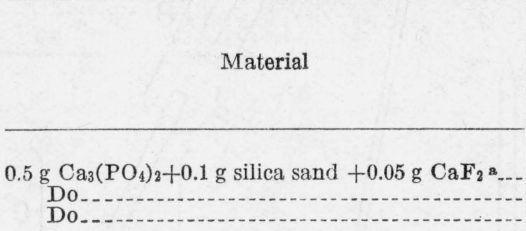 } & \multicolumn{2}{|c|}{ Fluorine present } & \multicolumn{2}{|c|}{\begin{tabular}{|} 
Fluorine found \\
by procedure de- \\
scribed. (Prelim- \\
inary fusion with \\
Na. $\mathrm{CO}_{3}$ )
\end{tabular}} & \multicolumn{2}{|c|}{$\begin{array}{l}\text { Fluorine found } \\
\text { by direct distil- } \\
\text { lation without } \\
\text { fusion with } \\
\mathrm{Na}_{2} \mathrm{CO}_{3}\end{array}$} \\
\hline & $\begin{array}{c}g \\
0.0230 \\
.0230 \\
.0230\end{array}$ & 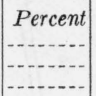 & $\begin{array}{c}g \\
0.0224 \\
.0225\end{array}$ & $\mid$\begin{tabular}{c|c} 
Percent \\
-2
\end{tabular} & $\stackrel{g}{ }_{0.0163}$ & $\mid$\begin{tabular}{|c|} 
Percent \\
-2
\end{tabular} \\
\hline $0.9 \mathrm{~g} \mathrm{Ca}_{3}\left(\mathrm{PO}_{4}\right)_{2}+0.10 \mathrm{~g} \mathrm{CaF}_{2} \mathrm{a}+0.2 \mathrm{~g}$ silica sand... & .0461 & $\mid-1-1-1$ & .0458 & & .0385 & \\
\hline $0.9 \mathrm{~g} \mathrm{Ca}_{3}\left(\mathrm{PO}_{4}\right)_{2}+0.10 \mathrm{~g} \mathrm{CaF}_{2} \mathrm{a}$ & .0461 & $\mid-1-1-1$ & .0464 & & 0366 & \\
\hline $\begin{array}{l}1.0 \text { g NBS Standard Sample } 56 \mathrm{a} \\
\text { Do } \\
\text { Do } \\
\text { Do }\end{array}$ & (1-n & $\begin{array}{l}\text { b } 3.56 \\
\text { b } 3.56 \\
\text { b } 3.56 \\
\text { b } 3.56\end{array}$ & & $\begin{array}{r}3.45 \\
3.52 \\
- \\
-1.2-\end{array}$ & 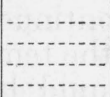 & $\begin{array}{l}3.34 \\
3.44\end{array}$ \\
\hline $\begin{array}{l}1.0 \text { g NBS Standard Sample } 120 \\
\text { Do } \\
\text { Do } \\
\text { Do }\end{array}$ & (-n-1-n & $\begin{array}{l}\text { b } 3.76 \\
\text { b } 3.76 \\
\text { b } 3.76 \\
\text { b } 3.76\end{array}$ & & $\begin{array}{r}3.73 \\
3.75 \\
-\end{array}$ & 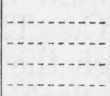 & $\begin{array}{r}3.55 \\
3.50\end{array}$ \\
\hline
\end{tabular}

a NBS Standard Sample 79 containing 94.8 percent of $\mathrm{CaF}_{2}$.

b Certificate value.

28 To prepare lead chlorofluoride wash solution: (a) Dissolve $10 \mathrm{~g}$ of lead nitrate in $200 \mathrm{ml}$ of water; (b) dissolve $1.0 \mathrm{~g}$ of sodium fluoride in $100 \mathrm{ml}$ of water, and add $2 \mathrm{ml}$ of hydrochloric acid; and, (c) mix solutions (a) and (b). Allow the precipitate to settle and decant the supernatant liquid. Wash four or five times with $200 \mathrm{ml}$ of water by decantation, and then add about 1 liter of cold water to the precipitate and allow to stand for 1 hour or longer with occasional stirring. Pour through a filter and use the clear filtrate. By adding more water to the precipitate of lead chlorofluoride in the beaker and stirring, more wash solution may be prepared as needed.

${ }_{29}^{29}$ Standardized by precipitating a measured portion with hydrochloric acid and weighing the silver chloride.

${ }^{30}$ Standardized by comparing with the standard solution of silver nitrate under the same conditions as obtain in the method. A convenient concentration is $0.1 \mathrm{~N}$.

${ }^{31} \mathrm{~A}$ cold saturated water solution of ferric alum (free from chlorides) to which has been added sufficient colorless nitric acid to bleach the brown color of the water solution. 


\section{DETERMINATION OF SILICA}

Fuse $0.500 \mathrm{~g}$ of the dried sample with $5 \mathrm{~g}$ of sodium carbonate, transfer the cooled melt to a platinum dish, leach with hot water, and filter when disintegration is complete. Return the insoluble residue to the dish by means of a jet of hot water, add $50 \mathrm{ml}$ of a 2-percent solution of sodium carbonate, boil for a few minutes, filter, and wash thoroughly with hot water. Reserve the combined filtrates $(A)$. Transfer the insoluble residue to a platinum crucible, ignite, fuse with $3 \mathrm{~g}$ of sodium carbonate, leach the cooled melt with hot water, and filter when disintegration is complete. Reserve the filtrate $(B)$.

By means of a jet of water transfer the insoluble residue to the platinum dish, then add $1 \mathrm{~g}$ of boric acid, $5 \mathrm{ml}$ of nitric acid, and $10 \mathrm{ml}$ of 60-percent perchloric acid. Heat until nearly all the perchloric acid is volatilized, cool, drench the residue with $5 \mathrm{ml}$ of hydrochloric acid, and then add $50 \mathrm{ml}$ of hot water. Digest on the steam bath for 5 minutes, and collect the precipitate on a small filter. Discard the filtrate and reserve the precipitate $(C)$.

To the combined filtrates, $(A)$ and $(B)$, which should have a volume of about $300 \mathrm{ml}$, add $1 \mathrm{~g}$ of zinc oxide dissolved in $20 \mathrm{ml}$ of diluted nitric acid $(1+4)$, boil for 1 minute, filter, and wash the precipitate thoroughly with hot water. Reserve the precipitate $(D)$. Add a few drops of methyl red indicator solution to the filtrate, nearly neutralize with nitric acid, and evaporate to a volume of $200 \mathrm{ml}$. Finish the neutralization of the concentrated solution by adding diluted nitric acid $(1+9)$ until the color is a very faint pink. Now add $1.0 \mathrm{~g}$ of zinc oxide dissolved in ammonium hydroxide and ammonium carbonate, ${ }^{32}$ and boil in a covered platinum dish until the odor of ammonia is entirely gone. After all the ammonia is expelled, add about $50 \mathrm{ml}$ of warm water, stir, allow to stand for a few minutes, filter, and wash the precipitate with cold water. Discard the filtrate and reserve the precipitate $(E)$.

With the aid of a jet of diluted hydrochloric acid $(1+19)$, transfer the precipitates $(C),(D)$, and $(E)$ from the papers to the dish in which the last precipitation was made. Ignite these papers and those used in the previous filtrations, and add any residue so obtained to the contents of the dish. Add $25 \mathrm{ml}$ of hydrochloric acid, and evaporate to dryness on the steam bath. Drench the residue with $10 \mathrm{ml}$ of hydrochloric acid, and then add $100 \mathrm{ml}$ of hot water. Digest on the steam bath for 15 minutes, filter, and wash with hot diluted hydrochloric acid $(1+19)$, and then with hot water. Return the filtrate and washings to the dish in which the evaporation was made, add $10 \mathrm{ml}$ of sulfuric acid, and evaporate until fumes of sulfuric acid are evolved. Allow to cool, add $100 \mathrm{ml}$ of water, digest for 5 minutes on the steam bath, filter, and wash with hot water.

Place the two papers containing the silica in a platinum crucible, char the paper without flaming, and finally ignite at $1,200^{\circ} \mathrm{C}$. Cool in a desiccator, weigh, and determine the silica by treatment with hydrofluoric and sulfuric acids in the usual manner.

Synthetic mixtures consisting of $0.5000 \mathrm{~g}$ of National Bureau of Standards Limestone $1 \mathrm{~A}+0.050 \mathrm{~g}$ of fluorspar $\left(\mathrm{CaF}_{2}\right)+0.25 \mathrm{~g}$ of tri-

${ }^{32}$ Transfer $1.0 \mathrm{~g}$ of zinc oxide and $2.0 \mathrm{~g}$ of ammonium carbonate to a small beaker, add $20 \mathrm{ml}$ of water and $2 \mathrm{ml}$ of ammonium hydroxide (sp gr 0.90 ), and digest on the steam bath until a clear solution is obtained. 
calcium phosphate were prepared and analyzed for silica by the foregoing procedure. Two determinations yielded 0.0713 and $0.0709 \mathrm{~g}$ of silica, respectively. The total content of silica was $0.0714 \mathrm{~g}$. In the analysis of Standard Samples of Phosphate Rocks 56a and 120, 7.7 and 11.0 percent were obtained, as compared with the certificate values 7.6 and 11.0 percent, respectively.

\section{DETERMINATION OF MANGANESE OXIDE (MnO)}

Transfer $0.500 \mathrm{~g}$ of sample to a $300-\mathrm{ml}$ Erlenmeyer flask and add $5 \mathrm{ml}$ of nitric acid and $15 \mathrm{ml}$ of 60 -percent perchloric acid. Heat to boiling, and continue the boiling until fumes of perchloric acid begin to be evolved. Remove from the source of heat, cool somewhat, and add $10 \mathrm{ml}$ of diluted hydrochloric acid $(1+1)$. Now boil the solution until most of the perchloric acid has been volatilized. Reduction of the volume to about $5 \mathrm{ml}$ is satisfactory.

Cool the solution and add $50 \mathrm{ml}$ of warm diluted nitric acid $(1+4)$ in which $0.5 \mathrm{~g}$ of boric acid has been dissolved. Digest for a few minutes, cool, filter through a paper of loose texture, and wash the flask and paper a few times with warm water. To the filtrate and washings in a $300-\mathrm{ml}$ Erlenmeyer flask add $5 \mathrm{ml}$ of 85 -percent phosphoric acid and 0.5 to $1.0 \mathrm{~g}$ of potassium periodate. Boil for $10 \mathrm{~min}-$ utes, cool, dilute if necessary, and determine the amount of manganese in the solution by comparing the color with that obtained by dissolving and similarly treating a material of known manganese content. It is obvious that it is desirable, but not necessary, to select a standard whose manganese content is approximately that of the unknown. The National Bureau of Standards Standard Samples of Phosphate Rocks $56,56 \mathrm{a}$, and 120 are satisfactory standards for materials containing up to 0.5 percent of $\mathrm{MnO}$.

No significant quantity of manganese remains in the insoluble residue if the National Bureau of Standards Standard Samples 56, 56a, and 120 are decomposed by this procedure.

\section{DETERMINATION OF THE ALKALIES}

\section{Determine the alkalies by the J. Lawrence Smith method. ${ }^{33}$}

\section{DETERMINATION OF SULFUR}

Sulfur is seldom determined. Detailed directions are therefore not given.

Total sulfur was determined by (1) digesting a 2-g sample with concentrated nitric acid containing bromine; (2) evaporating with hydrochloric acid to remove the nitric acid; (3) digesting the residue with hydrochloric acid $(1+1)$ and filtering; (4) adjusting the acidity to 1 to $2 \mathrm{ml}$ of hydrochloric acid in $100 \mathrm{ml}$ of solution; (5) precipitating the sulfate by adding barium chloride; (6) filtering and washing; (7) igniting the barium sulfate; and (8) correcting for sulfate obtained from reagents. No sulfur was found in the siliceous residue resulting from the evaporation with hydrochloric acid.

${ }^{33} \mathrm{~W}$ F. Hillebrand and G. E. F. Lundell, Applied Inorganic Analysis, p. 786 (J. Wiley \& Sons, New York N. Y.. 1929 ed.); G. E. F. Lundell and J. I. Hoffman, Outlines of Methods of Chemical Analysis, p. 75 and 185 (J. Wiley \& Sons, New York, N. Y., 1938 ed.). 
The percentages of total sulfur (as $\mathrm{SO}_{3}$ ) found in Phosphate Rocks $56 \mathrm{a}$ and 120 were 0.73 and 0.32 , respectively.

Pyritic sulfur was determined by transferring a 5 -g sample to an Erlenmeyer flask, adding $40 \mathrm{ml}$ of diluted hydrochloric acid $(1+1)$, boiling for 5 minutes, filtering, washing the residue thoroughly with diluted hydrochloric acid $(1+99)$, discarding the filtrate and washings, and then treating the residue as was done for total sulfur.

No significant amount of pyritic sulfur (less than 0.005 percent of S) was found in Phosphate Rock 56a and only 0.01 percent in Phosphate Rock 120.

Soluble sulfide sulfur, that is, sulfide sulfur that can be evolved by treatment with hydrochloric acid, was determined by the method that is used for this determination in cements. ${ }^{34}$ The sample is treated with hydrochloric acid and stannous chloride in a suitable flask, and the evolved gases are passed into an ammoniacal solution of zine sulfate. The stannous chloride prevents oxidation of sulfides by the oxidized constituents of the rock during the evolution. The sulfide which is absorbed in the ammoniacal zinc sulfate is determined by acidifying the solution with hydrochloric acid, and titrating with a standard solution of iodine.

Only 0.01 percent of sulfide sulfur (as S) was found in Phosphate Rock 56a and 0.05 percent in Phosphate Rock 120 . The foregoing results indicate that most of the sulfur in these two rocks is present as soluble sulfates.

\section{SPECTROCHEMICAL ANALYSIS (BORON)}

(a) QUALITATIVE EXAMINATION

Spectrochemical analyses of the two samples were made by B. F. Scribner of the spectroscopy section of this Bureau. The arc spectra were photographed in the region 2470 to $3300 \mathrm{~A}$, using carbon electrodes, and in the region 3200 to $4600 \mathrm{~A}$, using copper electrodes. The spectra were examined for the sensitive lines of $\mathrm{Ag}, \mathrm{Al}, \mathrm{As}, \mathrm{Au}, \mathrm{B}$, $\mathrm{Ba}, \mathrm{Be}, \mathrm{Bi}, \mathrm{Ca}, \mathrm{Cb}, \mathrm{Cd}, \mathrm{Ce}, \mathrm{Co}, \mathrm{Cr}, \mathrm{Cu}, \mathrm{Fe}, \mathrm{Ga}, \mathrm{Ge}, \mathrm{Hf}, \mathrm{Hg}$, In, Ir, K, $\mathrm{Li}, \mathrm{Mg}, \mathrm{Mn}, \mathrm{Mo}, \mathrm{Na}, \mathrm{Ni}, \mathrm{Os}, \mathrm{Pd}, \mathrm{Pb}, \mathrm{Pt}, \mathrm{Rh}, \mathrm{Ru}, \mathrm{Sb}, \mathrm{Sc}, \mathrm{Si}, \mathrm{Sn}, \mathrm{Sr}$, Ta, Th, Ti, Tl, U, V, W, Y, Zn, and Zr. No special effort was made to detect such elements as fluorine or sulfur, since other tests had already shown their presence. The elements found are as follows:

Tennessee Phosphate Rock 56a.

Major constituents: $\mathrm{Ca}, \mathrm{Al}, \mathrm{Fe}, \mathrm{Mg}$, Si.

Minor constituents: $\mathrm{Mn}, \mathrm{Na}, \mathrm{K}, \mathrm{Cr}, \mathrm{Sr}, \mathrm{Cu}, \mathrm{Ti}$.

Traces $\mathrm{Pb}, \mathrm{B}, \mathrm{Sn}, \mathrm{Ni}$.

Florida Phosphate Rock 120.

Major constituents: $\mathrm{Ca}, \mathrm{Al}, \mathrm{Fe}, \mathrm{Mg}$. Si.

Minor constituents: $\mathrm{Mn}, \mathrm{Na}, \mathrm{K}, \mathrm{Cr}, \mathrm{Sr}, \mathrm{Cu}, \mathrm{Ti}, \mathrm{Mo}, \mathrm{Ni}, \mathrm{V}$.

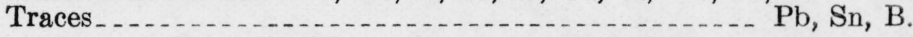

\section{(b) QUANTITATIVE DETERMINATION OF BORON}

Boron is the only constituent that was quantitatively determined by the spectrochemical method. This was done by comparison of the spectra of the two samples with the spectra of a set of standard mixtures photographed under comparable conditions. The standards

34 H. A. Bright, J. Research NBS 18, 137 (1937) RP968. 
were prepared to give a graded series of known concentrations of boron, using as a base a sample of tricalcium phosphate practically free from boron. The sensitivity of the test for boron is approximately 0.0001 percent. The precision of the method decreases as the concentration decreases, being within \pm 10 percent of the amount present for concentrations above 0.005 percent of boron and within \pm 20 percent below 0.005 percent. The boron reported as $\mathrm{B}_{2} \mathrm{O}_{3}$ was as follows:

Tennessee Phosphate Rock 56a: 0.005 percent of $\mathrm{B}_{2} \mathrm{O}_{3}$.

Florida Phosphate Rock 120: Less than 0.001 percent of $\mathrm{B}_{2} \mathrm{O}_{3}$.

It is interesting to note that the spectrochemical tests indicated higher percentages of manganese, copper, and boron in the Tennessee Rock than in the Florida Rock, and higher percentages of nickel, molybdenum, vanadium, tin, and chromium in the Florida than in the Tennessee Rock. This is in agreement with the following percentages of these constituents found by chemical methods. ${ }^{35}$

Tennessee Rock 56a: $\mathrm{MnO}, 0.18 ; \mathrm{CuO}, 0.002 ; \mathrm{B}_{2} \mathrm{O}_{3}, 0.005 ; \mathrm{NiO}$, $0.0005 ; \mathrm{MoO}_{3}, 0.0002 ; \mathrm{V}_{2} \mathrm{O}_{5}$, none found; $\mathrm{SnO}_{2}, 0.001 ; \mathrm{Cr}_{2} \mathrm{O}_{3}, 0.001$.

Florida Rock 120: $\mathrm{MnO}, 0.027 ; \mathrm{CuO}, 0.001 ; \mathrm{B}_{2} \mathrm{O}_{3}, 0.002 ; \mathrm{NiO}$, $0.003 ; \mathrm{MoO}_{3}, 0.002 ; \mathrm{V}_{2} \mathrm{O}_{5}, 0.015 ; \mathrm{SnO}_{2}$, $0.002 ; \mathrm{Cr}_{2} \mathrm{O}_{3}, 0.01$.

The ability to distinguish between such small percentages suggests the possibility of determining these and other minor constituents quickly and accurately by spectrochemical methods, provided that suitable standards are available.

\section{SUMMARY OF THE RESULTS OBTAINED IN THE COOPERATIVE ANALYSIS OF PHOSPHATE ROCKS}

Tables 2 and 3 give a summary of the results obtained in the analysis of the National Bureau of Standards Phosphate Rocks 56a and 120. The analysts mentioned in this tabulation have rendered valuable assistance in this work, and the authors express their deep appreciation to them.

${ }^{35}$ The boron was determined chemically by Lewis F. Rader, Jr., and W. L. Hill, Fertilizer Research Division, Bureau of Chemistry and Soils, U. S. Department of Agriculture, by the use of a method involving distillation and titration. The method will be published in the Journal of Agricultural Research. (Now in press.) 
TABLE 2.-Results obtained in the cooperative analysis of the National Bureau of Standards Standard Sample of Phosphate Rock 56a

[All results are based on a sample dried for 1 hour at $105^{\circ} \mathrm{C}$ a]

\begin{tabular}{|c|c|c|c|c|c|c|c|c|c|c|c|c|c|c|}
\hline $\begin{array}{l}\text { Analyst* } \\
\text { (by number) }\end{array}$ & $0_{\infty}^{\infty}$ & 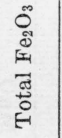 & 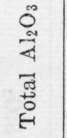 & 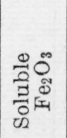 & 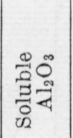 & $\underset{\substack{0 \\
0}}{0}$ & $\begin{array}{l}0 \\
b 0 \\
\sum_{1}\end{array}$ & 厌 & $\overbrace{01}^{\circ}$ & $\sum_{1}^{O}$ & $\begin{array}{l}0 \\
\text { జี } \\
\text { 乙 }\end{array}$ & $\begin{array}{l}0 \\
\ddot{H}\end{array}$ & 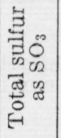 & $\stackrel{\overbrace{}}{E}$ \\
\hline & $\begin{array}{c}\% \\
\text { b32. } 80\end{array}$ & $\%$ & $\%$ & $\%$ & $\%$ & $\%$ & $\%$ & $\%$ & $\%$ & $\%$ & $\%$ & $\%$ & $\%$ & $\%$ \\
\hline & $\left\{\begin{array}{l}\text { e } 32.88 \\
\text { e } 32.96\end{array}\right.$ & 2.14 & 2.03 & 2.14 & 1. 77 & 45. 62 & 0.14 & 3. 49 & 11.02 & 0.18 & 0.30 & 0.25 & 0.73 & 0.09 \\
\hline & $\begin{array}{l}\text { d } 33.20 \\
\text { b32.85 }\end{array}$ & 2.24 & 2. 12 & & 20 & $\begin{array}{l}45.36 \\
45,49\end{array}$ & .18 & & 1150 & $-\cdots$ & & - & $\ldots$ & \\
\hline & e 33.15 & $\begin{array}{r}2.24 \\
-\ldots . . .\end{array}$ & $\begin{array}{r}2.12 \\
-\ldots-.-\end{array}$ & 2.11 & 1.88 & 45.49 & .10 & - & $\begin{array}{r}11.50 \\
-\end{array}$ & - & $\cdots$ & 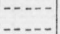 & $|-\cdots-|$ & \\
\hline & ๑33.26 & - n & ........ & 2. 17 & 1.90 & 45.56 & $\ldots$ & - & - & - & - & - & $\ldots \ldots$ & \\
\hline & $\mathrm{d} 33.12$ & & & 2. 11 & 1.87 & 45.48 & .12 & & & -1. & & $\cdots$ & $\ldots$ & \\
\hline & f 32.82 & 2.14 & 1. 98 & $-\cdots-$ & $\ldots$ & 45.48 & .12 & 3.53 & 10.92 & .18 & .24 & .31 & .73 & \\
\hline & & $\ldots$ & $-\infty$ & -- & - & 45.85 & .18 & -...... & -....... & -. & - &. & $\ldots \ldots$ & \\
\hline & $\mathrm{d} 33.17$ & 2.23 & 2.04 & 2.12 & 1. 94 & 45.55 & .13 & 3.66 & 10.60 & .19 & .31 & .29 & .72 & 07 \\
\hline $10 \ldots$ & e 33.05 & 2.16 & 1.93 & $-\cdots$ & $-\cdots$ & -...... & .12 & 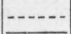 & $\ldots$ & $-\cdots$ & $\ldots-$ & $-\cdots$ & $\ldots \ldots$ & \\
\hline Averages... & g 33.01 & 2.18 & 2.02 & 2.13 & 1.87 & 45.55 & .14 & 3.56 & b11.01 & .18 & .28 & .28 & .73 & .08 \\
\hline
\end{tabular}

a Seven analysts reported an average of $0.53 \%$ of moisture, obtained by drying for 1 hour at $105^{\circ} \mathrm{C}$. The results varied from 0.36 to $0.64 \%$. Not much significance is to be attached to these values because the moisture content changes with atmospheric conditions.

b Gravimetric.-Precipitation with molybdate followed by two precipitations with magnesia mixture (J. Assn. Official Agr. Chem 8, 195 (1924).

- Gravimetric.-Two precipitations with magnesia mixture without preliminary precipitation with molybdate (J. Research NBS 19, 59 (1937) RP1010).

d AOAC, volumetric.

- AOAC, gravimetric.

$f$ Gravimetric. - Single precipitation with magnesia mixture after molybdate precipitation (J. Assn. Official Agr. Chem. 8, 194 (1924)).

$\mathrm{g}$ Special work at the National Bureau of Standards, and a careful consideration of all the methods employed indicate that 32.90 should be regarded as the most probable percentage of $\mathrm{P}_{2} \mathrm{O}_{5}$ in this sample.

$\mathrm{h}$ Special work at the National Bureau of Standards indicates that an uncertainty of at least $\pm 0.2 \%$ should be assigned to this value.

Analyst 1 also found $0.002 \%$ of $\mathrm{CuO}, 0.0005 \%$ of $\mathrm{NiO}, 0.0002 \%$ of $\mathrm{MoO}_{3}, 0.001 \%$ of $\mathrm{SnO}_{2}, 0.001 \%$ of $\mathrm{Cr}_{2} \mathrm{O}_{3}$, and no $\mathrm{V}_{2} \mathrm{O}_{5}$ in a 10 -g sample.

Analyst 7 also reported $0.005 \%$ of $\mathrm{B}_{2} \mathrm{O}_{3}$. B. F. Scribner of the spectroseopy section of the National Bureau of Standards found $0.065 \%$ of $\mathrm{B}_{2} \mathrm{O}_{3}$, spectrochemically. Analyst 9 also reported $1.56 \%$ of $\mathrm{CO}_{2}$ $0.26 \%$ of organic matter, $0.0021 \%$ of $\mathrm{As}_{2} \mathrm{O}_{3}$, and $0.39 \%$ of combined water.

\section{*ANALYSTS, BY NUMBER, AS LISTED IN TABLE 2}

1. James I. Hoffman, National Bureau of Standards, Washington, D. C.

2. E. W. Magruder, Chief Chemist, and W. A. Ryder, F. S. Royster Guano Co., Norfolk, Va.

3. W. Catesby Jones, Chief Chemist, John H. Elder, and James R. Lindsay, Commonwealth of Virginia, Department of Agriculture and Immigration, Richmond, Va.

4. C. A. Butt, Chief Chemist, and C. M. Cartledge, International Agricultural Corporation, East Point, Ga.

5. W. E. Dickinson, Chief Chemist, International Agricultural Corporation, Norfolk, Va.

6. P. McG. Shuey, Shuey \& Co., Savannah, Ga.

7. W. L. Hill, L. F. Rader, Jr., T. H. Tremearne, H. L. Marshall, and D. S. Reynolds, phosphate section, Fertilizer Research Division, Bureau of Chemistry and Soils, U. S. Department of Agriculture, Washington, D. C.

8. John B. Smith, Chief Chemist, W. L. Adams, and E. J. Deszyck, Rhode Island State College Agricultural Experiment Station, Kingston, R. I.

9. Egbert Janes, Chief Chemist, and H. H. Edwards, International Agricultural Corporation, Mulberry, Fla.

10. L. E. Dupont, Chief Chemist, International Agricultural Corporation, Wales, Tenn. 
TABLE 3.-Results obtained in the cooperative analysis of the National Bureau of Standards Standard Sample of Phosphate Rock 120

[All results are based on a sample dried for 1 hour at $105^{\circ} \mathrm{C}$. ]

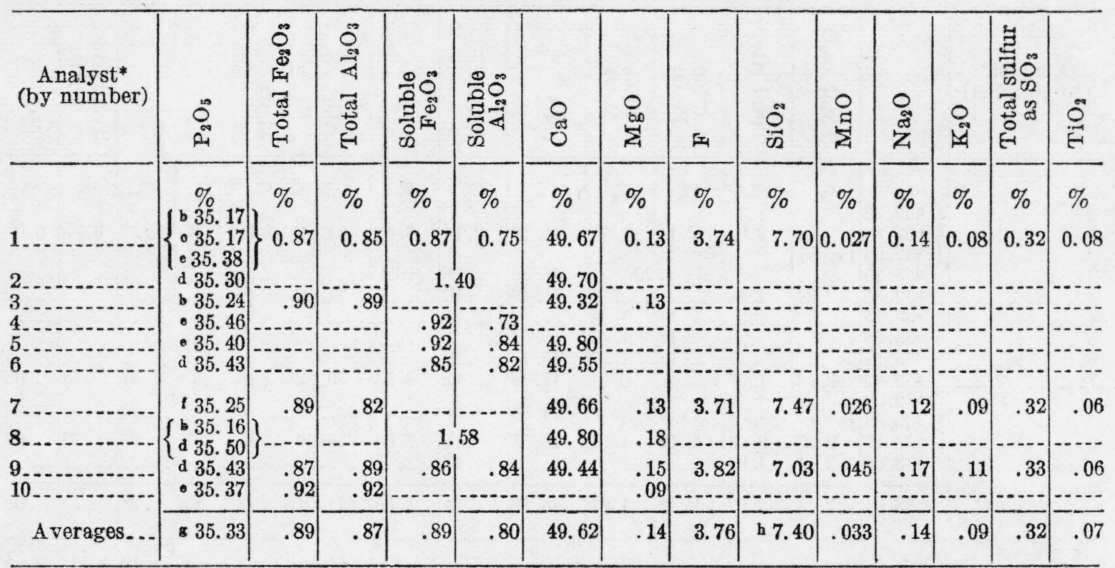

A Seven analysts reported an average of $0.53 \%$ of moisture, obtained by drying for 1 hour at $105^{\circ} \mathrm{C}$. The results varied from 0.43 to $0.66 \%$. Not much significance should be attached to these values, because the moisture content changes with atmospheric conditions.

bravimetric.-Precipitation with molybdate followed by two precipitations with magnesia mixture

(J. Assn. Official Agr. Chem. 8, 195 (1924)).

c Gravimetric--Two precipitations with magnesia mixture without preliminary precipitation with molybdate (J. Research NBS 19, 59 (1937) RP1010).

d AOAC, volumetric.

- AOAC, gravimetric.

1 Gravimetric.-Single precipitation with magnesia mixture after molybdate precipitation (J. Assn. Official Agr. Chem. 8, 194 (1924).

$\mathrm{g}$ Special work at the National Bureau of Standards, and a careful concideration of all the methods employed indicate that 35.20 should be regarded as the most probable percentage of $\mathrm{P}_{2} \mathrm{O}_{5}$ in this sample.

$\mathrm{h}$ Special work at the National Bureau of Standards indicates that 7.6 represents more nearly the true silica content of this material, and that an uncertainty of at least \pm 0.2 percent should be assigned to this value.

Analyst 1 also found $0.061 \%$ of $\mathrm{CuO}, 0.003 \%$ of $\mathrm{NiO}, 0.002 \%$ of $\mathrm{MoO}_{3}, 0.015 \%$ of $\mathrm{V}_{2} \mathrm{O}_{3}, 0.002 \%$ of $\mathrm{SnO}_{3}$ and $0.01 \%$ of $\mathrm{Cr}_{2} \mathrm{O}_{3}$. Analyst 7 also reported $0.001 \%$ of $\mathrm{B}_{2} \mathrm{O}_{2}$. B. F. Scribner of the spectroscopy section of the National Bureau of Standards found $\left\langle 0.001 \%\right.$ of $\mathrm{B}_{2} \mathrm{O}_{3}$, spectrochemically. Analyst 9 aiso reported $1.96 \%$ of $\mathrm{CO}_{2}, 0.32 \%$ of organic matter, $0.0018 \%$ of $\mathrm{As}_{2} \mathrm{O}_{3}$, and $0.12 \%$ of combined water.

\section{*ANALYSTS, BY NUMBER, AS LISTED IN TABLE 3}

1. James I. Hoffman, National Bureau of Standards, Washington, D. C.

2. E. W. Magruder, Chief Chemist, and W. A. Ryder, F. S. Royster Guano Co., Norfolk, Va.

3. W. Catesby Jones, Chief Chemist, John H. Elder, and James R. Lindsay, Commonwealth of Virginia, Department of Agriculture and Immigration, Richmond, Va.

4. C. A. Butt, Chief Chemist, and C. M. Cartledge, International Agricultural Corporation, East Point, Ga.

5. W. E. Dickinson, Chief Chemist, International Agricultural Corporation, Norfolk, Va.

6. P. McG. Shuey, Shuey \& Co., Savannah, Ga.

7. W. L. Hill, L. F. Rader, Jr., T. H. Tremearne, H. L. Marshall, and D. S. Reynolds, phosphate section, Fertilizer Research Division, Bureau of Chemistry and Soils, U. S. Department of Agriculture, Washington, D. C.

8. John B. Smith, Chief Chemist, W. L. Adams, and E. J. Deszyck, Rhode Island State College Agricultural Experiment Station, Kingston, R. I.

9. Egbert Janes, Chief Chemist, and H. H. Edwards, International Agricultural Corporation, Mulberry, Fla.

10. L. E. Dupont, Chief Chemist, International Agricultural Corporation, Wales, Tenn.

Washington, February 18, 1938. 